Apidologie, 1985, 16 (2), 165-170

\title{
A TECHNIQUE FOR YEAR-ROUND REARING OF BOMBUS TERRESTRIS (APIDAE, BOMBINI) COLONIES IN CAPTIVITY
}

\author{
Peter-Frank RöSELER \\ Zoologisches Institut (II) der Universität, \\ Röntgenring 10, D- 8700 Würzburg
}

\section{SUMMARY}

$\mathrm{CO}_{2}$-narcosis induces egg-formation in bumblebee queens prior to hibernation as well as after hibernation. Most of the treated queens started egg-laying within one week after being introduced into the nest box. The colonies developed in the same manner as colonies founded in the spring by queens collected in the field. This technique provides opportunities to rear bumblebee colonies year-round.

\section{INTRODUCTION}

The culture of bumblebee colonies is performed for pollination of agricultural crops as well as for scientific studies. Several attempts were made to improve seed production by augmenting bumblebees in the field : surface and underground domiciles were set out for overwintered queens or bumblebee colonies reared in captivity were brought to the crops at the beginning of the flowering period (reviewed by HOlm, 1966 and Alford, 1975; MacFarlane et al., 1983). Bumblebees were also used in greenhouses for pollination in plant breeding and even in gauze cages for pollination of small multiplication units (MORGNER, 1973). In several laboratories bumblebees are reared for scientific studies of social behaviour, learning behaviour, caste determination, and others. For all of these purposes it is desirable to be able to culture bumblebees throughout the year.

In temperate zones, bumblebees have one generation per year. Only few observations were published that a second generation could exist in the field (MEIDELl, 1968 ; MJELdE, 1981). Young queens which emerge during summer and autumn synthesize the reserves for hibernation during the first days after eclosion (Alford, 1969 ; Pouvreau, 1976). About the third day they leave the 
nest and are then ready to mate. After copulation the queens become lazy, scek suitable overwintering sites and enter diapause. The entering of diapause is an endogenous queen caste characteristic independent of temperature and light. Young queens left in the nest in a controlled climate room sit apart from the nest and do not participate in household tasks. Investigations have shown that the specific physiology of young queens is based upon a low juvenile hormone titre in haemolymph (RösEler, 1976; 1977). When newly emerged queens are treated with juvenile hormone, glycogen and lipids are not accumulated in the fat body, but oogenesis is induced and the queens start egg-laying after some days. A CO.-narcosis has a similar effect (Röseler and Rösller, 1984).

Queens overwintered in captivity are often difficult to activate. An increased temperature alone does not break diapause. HoLm (1965) has shown that queens of Bombus terrestris hibernated in a greenhouse under controlled conditions emerged over a period of more than two months. Presumably an endogenous readiness for breaking diapause is necessary for queens to respond to changes in environmental factors. It is, however, possible to activate hibernated queens by $\mathrm{CO}_{2}$-narcosis so that they start nest-building after a few days.

Since CO.-narcosis can be easily performed, I have used this technique to inhibit diapause as well as to activate overwintered queens. By both methods it is possible to rear bumblebees year-round. In the present paper the technique is described.

\section{MATERIAL AND METHODS}

Colonies of B. terrestris were reared in a controlled climate room at $+28^{\circ}-+30^{\circ} \mathrm{C}$ and $60 \%$ RH. In spring, queens were collected in the field prior to starting a nest. Queens with nests can be easily distinguished from others by their pollen collecting. Various techniques used for initiating a colony have been published (reviewed by HoLm, 1966; ALFord, 1975). The twocompartment system described by HASSELROT (1960) in which single queens were confined was used in my experiments. The bees were fed with water-honey solution $(50: 50, \mathrm{v}: \mathrm{v})$ and pollen collected by pollen-traps from honeybees. Only fresh pollen immediately deep frozen in small plastic bags after being collected in the evening was used.

At the climax of colony development new queens are reared. In $B$. terrestris there are no difficulties in mating. When young queens had left the nest box, they were placed in gauze cages $(50 \times 50 \times 50 \mathrm{~cm})$ with males from other colonies. Most of the queens mated between day three and six after emergence. Very seldom were matings of queens older than 10 days observed.

Young queens not used for immediate nest initiation were overwintered in a refrigerator. Two to three days after copulation queens were placed singly in glass jars lined with moist soft paper and stored at $+5{ }^{\circ} \mathrm{C}-+10^{\circ} \mathrm{C}$. Every month the queens were transferred to other jars in cases of mold development.

For $\mathrm{CO}_{2}$-narcosis queens were put in a glass jar and treated with a $\mathrm{CO}_{2}$ stream until they became immobilized. They remained in the closed jar for $30 \mathrm{~min}$. 


\section{RESULTS}

\section{Nest foundation without diapause}

Young mated queens were confined in gauze cages. One day after mating queens were narcotized with $\mathrm{CO}_{2}$, for $30 \mathrm{~min}$. When they were still lazy the following day, the narcosis was repeated. After $\mathrm{CO}_{2}$-treatment queens became very active and flew in the gauze cage. Two to four days following narcosis single queens were confined in nest boxes. Sometimes they became broody even in the gauze cage and started secreting wax. Since colonies were mostly available, single queens were often confined together with brood (old larvae or a freshly pupated comb) and some (2-5) newly emerged workers. This method facilitates nest foundation. Queens normally accepted the comb on the first day. Most of them started egg-laying within one week (Table 1). Workers older than five days were removed to avoid competition for egg-laying, and were replaced by newly emerged ones, if it seemed necessary, for feeding larvae or for fixing the comb. The colonies started in this way normally developed except that the first brood occasionally contained some males.

TABL. 1. - Number of Bombus terrestris queens initiating egg-laying following $\mathrm{CO}_{2}$-narcosis and confinement in nest boxes

\begin{tabular}{l|c|c|c|c|c|c|c}
\hline \hline & Total & \multicolumn{5}{|c}{ Days after confining } \\
\cline { 2 - 8 } & & $1+2$ & $3+4$ & $5+6$ & $7+8$ & $9+10$ & $>10$ \\
\hline Queens without hibernation & 46 & 10 & 11 & 12 & 6 & 3 & 4 \\
Hibernated queens & 48 & 11 & 21 & 7 & 3 & 1 & 5 \\
\hline \hline
\end{tabular}

\section{Activation of overwintered queens}

The shortest duration of overwintering tested was three weeks, the longest six months. Shorter or longer periods may be possible. To activate the queens a soft $\mathrm{CO}_{2}$-stream was introduced into the hibernation jars for $10 \mathrm{sec}$ in the evening. The jars were closed and put in a refrigerator at $+15^{\circ} \mathrm{C}$ overnight. The next morning the queens were transferred to gauze cages kept at room temperature. Two to three hours later the queens were taken out of the cages and stimulated to fly in the room for about $10 \mathrm{~min}$. Thereafter they were narcotized with $\mathrm{CO}_{2}$ for $30 \mathrm{~min}$. In the afternoon the queens were again stimulated to fly. When they were still lazy the next day, the $\mathrm{CO}_{2}$-treatment was repeated. Until nest initiation 
the queens were allowed to fly in the room twice daily for $10 \mathrm{~min}$. Three to six days after the last narcosis the queens were transferred to the climate room and confined in nest boxes as described above. Using this treatment the first eggs were also laid within one week (Table 1).

\title{
DISCUSSION
}

The method given in this paper makes it possible to rear bumblebees yearround. This is not only true for $B$. terrestris, but also for B. hypnorum and $B$. pratorum which we have occasionally cultured in captivity. Using this technique research is not limited to the summer and, moreover, colonies are available for pollination during spring when only queens or few workers are present in the field. A substantial prerequisite for year-round rearing, however, is to store a sufficient amount of pollen.

Received for publication in October 1984. Accepted for publication in February 1985.

\author{
ZUSAMMENFASSUNG \\ EINE METHODE ZUR ZUCHT VON VÖLKERN \\ DER HUMMELART BOMBUS TERRESTRIS (APIDAE, BOMBINI) \\ WAHREND DES GANZEN JAHRES
}

Eine $\mathrm{CO}_{3}$-Narkose induziert die Eibildung bei jungen Hummelköniginnen sowohl vor der Überwinterung (und verhindert damit die Diapause) als auch nach der Überwinterung. Die meisten der so behandelten Königinnen begannen innerhalb einer Woche, nachdem sie in den Nestkasten eingesetzt worden waren, Eier zu legen. In ihrer Entwicklung unterschieden sich die Völker nicht von solchen, die im Frühjahr von gefangenen Königinnen gegründet worden waren. Man kann deshalb die Methode der $\mathrm{CO}_{2}$-Narkose benutzen, um Hummelvölker das ganze Jahr hindurch zu züchten.

\section{RESUME}

\section{TECHNIQUES POUR ELEVER DES COLONIES DE BOURDONS BOMBUS TERRESTRIS (APIDAE, BOMBINI) EN CAPTIVITE TOUT AU LONG DE L'ANNEE}

Une anesthésie au $\mathrm{CO}_{2}$ induit la formation d'œufs chez les reines de bourdon avant l'hibernation aussi bien qu'après. La plupart des reines traitées ont commencé à pondre durant la semaine qui a suivi leur introduction dans la boîte de nidification. Les colonies se sont développées de la même manière que des colonies fondées au printemps par des reines prélevées dans la nature. Cette technique permet d'élever des colonies de bourdons durant toute l'année. 


\section{REFERENCES}

Alford D.V., 1969. - Studies on the fat body of adult bumble bees. J. Apic. Res., 8, 37-48.

ALFORD D.V., 1975. - Bumblebees. - Davies-Poynter, London.

Hasselrot T.B., 1960. - Studies on Swedish bumblebees (genus Bombuts Latr.) : their domestication and biology. Opusc. Ent. Suppl., 17, 1-192.

Holm N., 1965. - The emergence of bumble bee queens (Bombus Latr.) under controlled conditions. Ustav Vědeckotechnických informaci MZLVH, 4, 79-83.

Holm N., 1966. - The utilization and management of bumble bees for red clover and alfalfa seed production. Annu. Rev. Ent., 11, 155-182.

Macfarlane R.P., Griffin R.P., and P.E.C. Read, 1983. - Bumble bee management options to improve "grasslands pawera》 red clover seed yields. Proc. N. Z. Grassland Ass., 44, 47-53.

Meidell O., 1968. - Bombus jonellus (Kirby) (Hym., Apidae) has two generations in a season. Norsk ent. Tidsskr., 14, 31-32.

Mjelde A., 1981. - Pers. Communication on B. pascuorum.

Morgner F., 1973. - Aufzucht von Hummelvölkern (Bombus spp.) und Blattschneiderbienen (Megachile rotundata) und ihr Einsatz zur Bestäubung kleiner Vermehrungseinheiten. Z. Pflanzenzüchtg., 70, 246-258.

Pouvreau A., 1976. - Contribution à la biologie des bourdons. Etude des quelques paramètres écologiques et physiologiques en relation avec l'hibernation des reines. Thèse Doct. Sci., Univ. Paris-Sud, Orsay.

RöSELER P.F., 1976. - Juvenile hormone and queen rearing in bumblebees. In : Lüscher M. (ed).) : Phase and caste determination in insects, Pergamon Press, Oxford, 55-61.

RöSEler P.F., 1977. - Endocrine control of polymorphism in bumblebees. Proc. VIII Int. Congr. I.U.S.S.I., Wageningen, 22-23.

Röseler P.F. and Röseler I., 1984. - Der Einfluß von $\mathrm{CO}_{2}$ und der Kauterisation der Pars intercerebralis auf die Aktivität der Corpora allata und die Eibildung bei Hummeln (Bombus hypnorum und Bombus terresiris). Zool. Jb. Physiol., 88, 237-246. 